\title{
Federalism as Protagonist or as Nemesis for Nigeria'S Political Development
}

\author{
Babatunde Oyedeji ${ }^{1}$ \\ ${ }^{1}$ Dept of Politics \& International Relations, Lead City University, Ibadan \\ Correspondence: Babatunde Oyedeji, Dept of Politics \& International Relations, Lead City University, Ibadan. \\ E-mail: tumoxoye@gmail.com
}

Received: April 28, 2017

doi:10.5539/mas.v11n7p57
Accepted: May 23, 2017

Online Published: June 9, 2017

\begin{abstract}
Despite the plethora of findings and feelings surrounding federalism and the acerbity of the cynical discomfort at the negative nuances about the ideology, the federal system has produced stable and settled societies in Canada, Australia, the United States of America, India, Germany, Switzerland, New Zealand, Brazil, Malaysia and Mexico. Nevertheless, the frequent conclusion is its inherent attraction to 'inevitability of instability' generally in Africa and specifically in Nigeria. This typology seems to apply to developing countries more than others, in any case, at least nineteen countries containing some $40 \%$ of the world's population. This puts and acute pressure on Nigeria, the surviving big federal country in Africa. It can be asked, did the British leave meaningful alternatives to federalism whilst ruling Nigeria between 1900 and 1914 and 1960? Can’t it not be deduced that federalism was indeed a natural product of decisions and phenomena like the Indirect Rule, the political activism on the part of Southern Nigerian politicians. Was the complex nature of Nigeria's federalism a product of residual colonialist autocracy? The paper aims at delving into variants contributing to the sticky challenge and complexities of the Nigerian federation. It would be expository and analytical as it examines the advantages and attractions prior to the shortcomings and deficiencies of federalism. There would be references to the applicability of these deductions to the Nigerian example.
\end{abstract}

Keywords: federalism, region, government, Nigeria, constitution

\section{Introduction}

Plenty of opprobrium and ominous fingers are perennially pointed at Nigeria's brand of federalism, its constitution, its history; it carries 'the inevitability of instability' (O' Connell: 1967/181-191); 'it is overcentralized' and 'overbloated', (Irikefe, 2013, p.71); 'it is heterogenous'; 'it is conflictual and divisive', 'Nigeria still totters on as a toddler', (the Economist, p 108). To the Ango Abdullahi led Arewa Development Foundation, ' '.......the current state of the Nigerian State is untenable, is not sustainable, we will support its balkanization' (Ayoade et al; 2014 p. 25); 'when the time comes, Nigeria will destabilize' (Aguda in Ayoade et al. p. 107, 'phony amalgamation', (Ayoade, 2010, p.4). To a foremost nationalist, Chief Obafemi Awolowo, the country was no more than 'a geographical expression'; to northern region leader, Ahmadu Bello, Nigeria was a product of 'the mistake of 1914' unleashed by the colonial masters; to prominent nationalist, Dr Azikiwe, it was better to find a peaceful rather than a bitter method of separation. Whilst weighing the obtuseness of Nigeria's governance structure, Ojo declared that Nigeria 'runs perhaps the most centralized federation in the whole world'. Maddox also believed that 'federalism never worked successfully whether in military dictatorship or civilian absolutism' (2014; p 110).

\subsection{Characterization of Nigerian Federalism}

The federalist structure was imposed on Nigeria in 1946 through Richards Constitution, the 1951 McPherson Constitution and the 1954 Lyttleton Constitution all of which had Nigerian leaders' participation but nonetheless generated heavy-weight injection of cynicism with nationalists, politicians and analysts. Nigeria was a product of 'territories acquired by the British at different times' through 'gunboat diplomacy, military expeditions and treaty-making (Ayoade, 2014; ibid, p.3). Richard Akinjide adjudged the 1914 Amalgamation as a 'fraud' because the Amalgamation was 'administration of the North and South and not the people'(Akinjide, 2000, p.2).

Ayoade also regarded Chief Awolowo's characterization of the Amalgamation as a mere geographical 
expression' noting that the British were indifferent to 'the mix and proportion of the conglomerate state' (Ayoade ibid. p3). Adeolu Adebayo quoted some early writers who adjudged Nigeria as 'a mad country' whose population figures of the 1950s are fictitious and doctored by the British to favour the northerners'(Adeolu p 62).

\subsection{Theoretical Base}

Several theories have often been advanced to support federalism. Daniel Jonah Elazar provides 'the simplest possible definition' of federalism as 'self-rule plus shared rule', 1991; Exploring Federalism; University of Alabama Press, Tuscaloosa; $p$ 29). The validity of the Democratic Theory is frequently disputed especially for states on grounds that democratic tenets often tend to restrict minority rights and put the sections of society at a disadvantage; thus the objective of democratic theory is not served by federalism. The Hierarchical Theory is probably more applicable to Nigeria's federalism as the relationship of the tiers can only be hierarchical whether collectively or separately. The nature of inter-governmental relations amongst the states and the centre is more like an Overlapping Authority Model or the Inclusive Authority Model involving a superior jurisdiction range of powers for the centre as against the weaker and subsidiary role of the lower state and local government tiers (Eneanya Nduka Augustine; 2014, p552-4). William H Ricker pushes the military factor as powerful reason for federalism, that the fear of the unpredictable potentially bellicose or ambitious neighbor is the spur to try and forge a federation. He argued that Nigerian apprehension arose out of the restive and potential expansionist tendencies by Kwame Nkrumah of Ghana especially his agitations for a Pan African unity government constituted an external threat to Nigeria. Many federal countries carried this fear, Babalola; 2013; The Origins of Nigerian Federalism: The Rikerian Theory and Beyond; FG Federal Governance, a graduate journal, 10(1).

K C Wheare ascribed the 'federal principle' to 'the method of dividing powers so that general and regional governments are each, within a sphere, co-ordinate and independent of one another' (Odion; 2011). Thus there has to be at least two levels of government each to be financially independent to execute its prescribed functions, there has to be an independent judiciary for conflict resolutions. Similarly, Obafemi Awolowo insisted that 'if a country is bilingual or multi-lingual like Nigeria, the constitution must be federal, and the constituent state must be organized on linguistic basis' and that any experience with a unitary constitution 'would fail' (Odion; 2011, ibid). To Burgess, federalism is an ideology in the system of government reflecting a synergy between 'human relations and conduct' whilst federation is an ideology and a guide to action.

\section{The Deficiencies of Federalism}

Federalism carries some negativity alongside some benign cover for its adherents. One major effect of federalism is the distinction or the kind of support offered by the colonial masters to whichever was the preferred side of the Nigerian equation. The British established the Oil Rivers Protectorate, the Niger-Delta Protectorate along with various kingdoms (Oyo, Lagos, Calabar, Brass, Itsekiri, Benin, Tiv and Sokoto Caliphate) erstwhile independent states and kingdoms for British-own independent political and economic interests. Similarly, the authentic reason for the 1914 Amalgamation of the Southern and Northern Protectorates was neither altruistic nor an outflow of a 'crusading genius' (Sagay; 2013). The reason was to avoid spending British taxpayers' money in administering the North, which was not economically viable', the only way to cut their losses was to amalgamate the North and the South and transfer money from the economically buoyant South to the North.

The Phillipson Report disclosed that from 1906, when Southern Nigeria and Lagos became one Administration, the financial resources of the South had increased 'with astonishing rapidity' whereas the North 'largely dependent on the annual grant of the imperial government was barely able to balance its budget with the most parsimonious economy of native administration and revenue resulting from direct taxation'. The revenue accruing to the North from indirect taxation, i e, the revenue accruing to the North from custom duties as compared to that accruing to the South from the same source was derisory.

The British therefore ensured the political domination of the North by rigging the first census for the North in 1952 and the 1959 elections (Ajayi, 2012, p. 145), and with power in the hands of Arewa North, the census arrangement has been maintained in all successive censuses since 1952 i.e. 1962, 1963, 1972 and 1991, which is why the North insisted successfully that it should have at least $50 \%$ of the seats in the Central Legislative Chambers of Nigeria at the Special Constitutional Conference in Ibadan in 1950.

In 1947, the late sage, Chief Awolowo observed that "Nigeria is not a Nation, it is a mere geographical expression. There are no Nigerians in the same sense as there are English, Welsh, or French. The word Nigeria, is merely a distinctive appellation to distinguish those who live within the boundaries of Nigeria from those who do not”. Whilst Chief Awolowo was brutally frank and 'somewhat over-principled and rigid in his pronouncements, Northern Nigerian leaders showed a steady loyalty to colonialists and wanted Britain to stay for a longer period' (Adeolu, 2010, p. 73), which was why the North virulently disagreed with the Enahoro motion calling for 
independence in 1953 as against the North's preference for 'as soon as possible' to replace the 1956 date proposed by Enahoro. There was no love lost as between the North and the South, the North and its leadership 'looked disdainfully to the people of the South'; upon his first visit to Lagos in 1949, the Sardauna described Lagos and the South as 'alien to our ideas'; he felt that members of the South 'might well belong to another world' (Meredith Martin; 2005).

There are specific issues peculiar to Nigerian federalism in terms of north/south regional cleavages standing as disintegrative factors up to and since independence:

a) There is a clear disparity and unevenness of natural, ecological and material resources causing continuous strains and imbalances which are precursors to bitter rivalry and questionable resource distribution. Natural disequilibrium in Nigeria's regions pre-dated Independence but were simply ignored or treated disdainfully by colonialists who thus entrenched the foundation for future instability. The British did not have the will, the time or intention to attempt to quell the furor of intertribal schisms. The most obvious imbalance was the division by Governor Richards, following his 1946 Constitution, when he redrew the map of Nigeria. He refused to leave the natural boundaries situated in the Benue River (on the right) and the Niger River (on the left) preferring to use that occasion to punish the South for always agitating for an end to colonialism and demanding the departure of the British. This unjust decision defied K C Wheare and Mill's 'Law of Instability' ${ }^{17}$ in a brutally ominous manner (Falola: 2016 pp 186, 193). This egregious violation of the architecture of Nigeria's history and future was described by $\mathrm{H} \mathrm{L}$ Bretton as 'one of the greatest acts of gerrymandering in history' (Elaigwu \& Akindele; 1996). Similarly Ayoade et al. cited John Stuart Mill's declaration that a federation is morbid if one part of the federation is bigger than the sum of the other parts (Ayoade JAA 2014; p 113).The possible alibi by the British was the residues of the Dan Fodio Jihad wars where the Jihadists tried to overrun the South militarily, but were halted by the Ibadans at the battle of Oshogbo in 1840 .

b) The untreated disease of pro-North obsession by colonialists was shown in the quota system designed in 1958 first for fresh recruitment, then in 1961 (by the Tafawa Balewa government) its extension to officers' recruitment so that .......regardless of qualifications and competence, $50 \%$ of military officers were to come from the Northern Region, 25\% each from the Eastern and Western Regions Irikefe; p.28. In any case, the British were determined and made sure that the North remain politically dominant in the Country and to be in the position to control power and authority so that the rest of the Country would be 'the foot-stool of the North'. The 1952 national population census put the north overwhelmingly ahead of the south; instead of basing the calculations on the number of registered voters, since women had no franchise at that time in the North, the Commission based its calculation on population which would give the North a much higher figure. "Northern region was awarded 174 instead of 92 in 1954 in a 320 member assembly, Eastem Region 73, Western Region 62”, (Meredith Martin 2005/75). Thus Smith of the Colonial Office concluded thus 'It is therefore clear that the North if it can stay united, has every prospect of dominating the Federal Government for many years to come' (Ajayi Olaniwun 2015/63). Akinjide asserted that the British evinced same preference for Northern Nigeria. There was the Northern leaders' intense deference to colonial officials; for instance, the Sheu of Borno wrote to Lord Lugard as quoted by Ajayi', "Letter from the slave of God.......to our grand helper, our prop, the solver of our difficulties, the one who carries our heavy burdens....... May God prolong your life, the keeper of those who keep others". The Emir of Nupe also wrote to Lord Lugard "Many beautiful salutations, a clean love. My present to you is two turkeys, one package of plantains and one of limes" (Akinjide; 2001). The British worked arduously to ensure Northern Nigeria interest succeeded colonial administration in 1960. Governor Sir James Robertson prematurely invited Sir Abubakar Tafawa Balewa to form the government even when full results of the 1959 general elections were not available to 'frustrate the alliance between the NCNC and the Action Group. The Prime Minister steadfastly personalized the management of Nigeria's foreign policy with Peter Stallard former British colonial officer'. In any case, a former British colonial officer Harold Smith affirmed that “....the British Home Office ordered the rigging of the 1959 Federal Election" in preference for a 'feudalist and conservative North' as against a querulous and restive South (Irikefe, 2013/59 \& Ajayi, 2012, p. 145).

c) Federalism tends to emphasize the State, Town and Locality of the citizenry against one another, thus tends to fuel ethnicity, separateness, potential tension and bickering. Many of the form filling and documentation for official paper work in Nigeria require details of birth, origin of parents and grandparents of the applicant. This affects probably all paper work involving Nigeria's bureaucracy. 
This tends to undermine understanding and unity.

d) Most State Governments in Nigeria erect various barriers against non-indigenes, denying them official rights in education, health, land, residency and employment matters. Different requirements are inflicted on non-indigenes for access to schools, employments, scholarships, land ownership, grazing and agricultural pursuits which constantly lead to blood letting in Plateau and Benue, North Central Zone and parts of the Southem States. This separateness carried a double-edged disability, exclusivity in communal relations and vulnerability to mass attacks in the event of a social crisis and rioting by the indigenous community.

e) In any case, the ostracisation of non-indigenes has a history with strangers being confined residentially to Sabon-Gari to the North and to the South (Karl Maier, 2000, p.11).

f) The depth of the suffering of the Niger/Delta citizenry is so outlandish that even the Willink Commission of 1958 declared '.......it is not easy for a government or a legislature operating from the inland to concern itself or even fully understand the problems of a territory where communications are so expensive and education so scanty in a country which is unlikely ever to be developed' (Irikefe, ibid, p114).

g) The extra rigid conditions for amending the Constitution and the creation of States produces long lasting enduring rifts, bitterness and rancor that are protracted and harden unto a boiling point. It is usually hard to find and effect reconciliatory and peaceful conflict resolution options. Despite the recurrence of strong agitation for State creation by various communities in North Central and South-South of Nigeria between 1950s and since, Nigerian's political elites did not successfully create one state except the fortuitous and singular example of the Mid West State. That State was created in 1963/64 out of the conspiracy of the 2 parties (Northern People's Congress -NPC- and the Nigerian Council of Nigerian Citizens (NCNC) Coalition which saw the raging crisis in the Action Group as an opportunity to crush Chief Awolowo's Action Group opposition party. The ruling coalition rejected pressures to create States in the East and in the North despite equally strong pressures from minorities in both states. As concluded by Nwabueze, 'the absence of truly integrative national parties remains perhaps the biggest obstacle to federalism as an active force in forging national unity in Nigeria'; (Nwabueze, 1983, p.36).

h) The bugbear of tribalism has plagued Nigeria with ceaseless ferocity before, during and after independence. Various similes have been tagged on Nigeria's federalism such as 'sub-nation' and 'ethnic nationalism', 'Politics of precarious balance, a society of irrepressible pluralism and hostile sub-culture” (Obiozor; October 8, 2015), 'tribal relations', 'group morphology', 'ethnicity and ethnic politics', (Tepecikiioglu; 2012; 4-6 July 2012, p.8) 'a medley of peoples', 'joint identity and integration crisis', ' clandestine tribal organisations', federalism is inherently unstable' (Ojo, 2009; pp 384-395), divisive tendencies, 'politically explosive inter-segmental inequalities', structural imbalance', assymetrical territorial association', 'diaspora component units, 'political power will remain in the north perhaps forever', political instability, unpalatable effect of the lopsidedness', sectional imbalance and bias', the convoluted federation', problematic nature of citizenship in the country', 'crippled giant' (Title of Eghosa E Osaghae's Classic 2011); 'Neither a national consensus nor a binding ideology' (Maier, 2000); 'Nigeria is not a developing nation, it is underdeveloping', pxxi, ibid, In Nigeria, privilege can be fleeting, (ibid p 2).

To Lawrence Chinedu Nwobu, Britain knowingfully created in Nigeria, a tinderbox of contradictions and endless conflicts' (Nwobu; 2013; Mar 27); Final Solution: De-Amalgamation and The Advantages of Breaking Up Nigeria' village-square.com.....1/13/2017. L O Dare described federalism as 'a state of uncertainty and vagueness' (Irabor Peter Odion; Mar 30, 2011); A Critical Assessment on Nigerian Federalism; Path to a True Federal System' vanguard online. Nnamdi Azikiwe was so nervous about the future of Nigeria's federalism that he felt it was 'better for us and many admirers abroad that we should disintegrate in peace and not in pieces...'... along with the prediction that 'the experience of the Democratic Republic of the Congo will be a child's play if ever it comes to our turn to play such a tragic role' (Nnamdi Azikiwe; 1964), this could be joined with Dr Michael Okpara's belief that the 'two worst threats to Nigerian unity are 'the practice of regionalism' and of the territorial preponderance of the northern region within Nigeria (Nnamdi Azikiwe in Falola; 2016; ibid. p 193). Similarly, James O'Connell added that 'the constitutional settlement at independence in many Anglophone African countries particularly Nigeria, sowed the seeds of later trouble'.

It could be reasonably be said that Nigeria has 'the people locked into a nation state they had no part in designing' (Karl Maier; 2000; ibid, p. 7). 'It suited the emirs who were allowed to maintain their power and even to extend it over smaller pagan communities that they never before controlled'. In turn the British shielded the North from 
the advance of Christian missionaries and Western education from the South (Karl Maier, 2000; ibid; p. 11). The decision to abolish the regions and their powers of autonomy set into motion a constitutional crisis about how Nigeria was to be governed, a crisis that persists until today, (p 13). After a deeply incisive review of British divisive policy in Nigeria, Olaniwun Ajayi poignantly concluded 'the retrogression, disharmony, animosity, and instability in Nigeria arose from the dogged and determined resistance of both the Whitehall and Church House in favor of Northern Nigeria. The unyielding and tenacious resistance brought about the incongruent political structure in the country. If the ethnic nationalities had been allowed, each to be in their political habitat, harmony, peaceful coexistence and progress would have been in place'. To crown the septic cynicism of analysts about Nigeria, Irikefe described it as '....... a static and restless state because it is a structure built on fraud and contradictions. It proclaims itself as federal but it is unitary, secular but theocratic, civilian but military', (Irikefe; 2013; p 69).

\subsection{Additional Disadvantages of Federalism are:}

- It diminishes political rights of citizens as top positions are rotated within the main ethnic groups, provisions to offer redressive panaceas for injustice and opportunity lopsidedness have proved unavailing for decades,

- It places too much emphasis on ethnicity, where do parents come from, giving little scope for understanding, nationhood and unity especially in a developing country,

- Some state governments deny access to non-indigenes for facilities in health, education, housing, employment. The factor of residence is subsumed or ignored as valid basis of citizenship, (Nnamdi Azikiwe in Toyin Falola, 2016; ibid, p. 193 (Karl Maier; 2000; ibid, p. 7)(Irikefe; 2013; p 69).

- The complex conditions for state creation is a spur to ethnic tensions, Section 8 of the 1999 Nigerian Constitution demands as requirements (a) a two-thirds majority of members of Senate, House of Representatives and local councils of the area asking for a state, (b) a two-thirds majority in a referendum from the area of demand, (c) positive support from a simple majority of all states in the country, and (d) a two-thirds positive passage by both Houses of the National Assembly. As consequence of this steep conditions, no new state has been created by any Nigerian civilian government since 1964 (ref Chap 8 of 1999 Nigerian Constitution p LL 26-7). As desirable and as compelling as state creation was in Nigeria's evolution, it has led to what John Campbell (2010, p 8), described as 'morselisation' thus 'increasing the power of the Federal Government because so many of the states are utterly on it for nearly all of their revenue'.

- $\quad$ Federalism creates more opportunities for corruption, incompetence and sloggishness, (Jonathan Hill; Nigeria Since Independence: Forever Fragile? Amazon.com Springer Shop)

- $\quad$ Problem with Nigeria, Unitary Content but Federal Label in Sam Momah; 2013.

Despite formidable disincentives and shortcomings identified with Nigerian federalism, there are equally impressive attractions and inducements to federalism which we proceed to examine after a typical definition of federalism by KC Wheare, 1967:

'Anew military insecurity and of the consequent need for common defence, a desire to be independent of foreign powers, and a realization that only through union could independence be secured, a hope of economic advantage from union; some political association of the communities concerned prior to their federal union; either in a loose confederation, as with the American states and the Swiss cantons, or as parts of the same Empire, as with the Canadian and Australian colonies; geographical neighborhood; and a similarity of political institution', (KC Wheare; ibid, p 37)

\subsection{Federalism as Experiment in Nigeria}

- $\quad$ Nigeria was governed as a unitary state by British colonial officers between 1900 and 1946. It survived that unitarism because up to the end of the 2 World War, there were no strong political parties beyond the National Youth Movement and the former defunct Nigerian National Democratic Party founded by Herbert Macaulay in 1922. By the late 1940s and the 50s, the Nationalists (especially of Southern Nigeria) concentrated on demands for tertiary education, higher worker wages, deeper democracy, and independence for Nigeria. In any case colonialism was largely characterized by trade, pacification and only the most rudimentary form of administration (Ruth First; 1970; p29, 31) thus colonial administration resembled armies of occupation and colonial administration 'manipulated local, regional and ethnic differences to emphasise divisive rather than unifying national interests......the Nigerian constitution most notoriously of all, not only ensured that politics would be regional, but that the Federation itself would be perpetually on 
the brink of crisis, (Ruth First; ibid; p.54).

- Governor General Richards and his promulgation of the Richards Constitution in 1946 was followed by his massively obtuse division of Nigeria into three territories, the West and the East sharing $21 \%$ of the territorial spread, the North being allotted a whopping $79 \%$ bulwark of Nigeria. Surprisingly nationalist leaders of the South did not apparently raise dust on this obnoxious decision which contradicted expectations that any sub-division of the country would defer to the natural boundary setting provided by the River Benue on the East, and the River Niger on the West which itself would still have produced a Northern Region that itself would be more than twice as big as the South. The imbalance sowed the seed of endemic drift in the Nigerian political equation which even the subsequent creation of states has not totally solved'.

\subsection{Advantages of Federalism}

a) A principal advantage of federalism is the opportunity for decentralization, devolution and deconcentration. With time, the nation's capital and its urban centres become densely populated with the tendency for rural-urban migration and the natural flow of governance momentum,

b) Major governmental thrusts into state and local governments and parastatals whose creation entail enactment of laws and regulations which tend to reduce the monopoly of the centre and increase the spread-out of the provinces and sub-units,

c) It encourages Nigerians to move around the country thus enhancing integration, it is a mobilization-enhancing factor as the social distance among people and places becomes narrower and bridge-building is facilitated. Over time, communities become closer as urbanization takes over from ruralness,

d) Amajor product of federalism atop an heterogeneous country is the tendency to procure some integration or centripetality within the multiple tribes, cultures, and languages (Kehinde \& Olarotimi; 2013). Such integration should precurse some cordial co-existence amongst the diverse nations inhabiting the nation. In any case federalism should use the tool of coordinate partnership among parties 'with equal claims to legitimacy who seek to cultivate their diverse integration within a common social order' (Bechna; 1931), (Thomson Gale; 2008).

e) The design, crafting and concurrent adoption of a written constitution is a distinguishing mark of federalism. The constitution commits to a covenant specifying terms by which power is shared in the system. Those terms are usually viewed as rigid and intentionally made difficult to alter. The cumbrous nature of an amendment process is inevitable to avoid trifling amendment demands or social instability. The caveat is to assist the durability and suitability of the document and its momentum, some countries install constitutional courts to take on and administer constitutional disputes, others are content with the regular courts, Nigeria falls with the latter. As an inherently unstable country, there has been a constant stream of agitations, unrest and dissatisfaction including calls for restructuring of the country, adjustment of the fund allocation formulae, the mode of resource-control, the issue of a more acceptable census , agitation for more states and local governments, even occasional demand for secession.

f) Because of its frequency and often the fragility of the demands, the federal government usually shrugs them off as rantings from opposition parties or disgruntled groups intent on destabilization or distracting the ruling government. In any case the Constitution and the Courts form a fall-back for discontent albeit inadequately,

g) The very existence of similar layers of its authority - the Legislature, the Executive and the Judiciary at both the centre and the state levels reinforces the concept of federalism and the concept of separation of powers (Tepeciklioglu; 2012; ibid). The caveat is the clarity of functional demarcations usually specified in each federal constitution. In any case what seems indubitable is the unique nature of every occurrence of federalism.

h) Federalism can foster peace, prevent wars and fear of wars as the strength of the collective seems to be the beginning of peace-seeking by querulous and bellicose neighbors. It can promote economic prosperity through the economies of scale inherent in potential agreements that large states could forge. Same goes for political influence that could emerge from bigness and respect and esteem provided there is a high level of governance and achievement capacity(Stanford Encyclopedia of Philosophy; Jan 5, 2003).

i) Additional advantages of federalism were: 
- Protection of the interest of minority groups,

- Managing the populations in the large geographical area of Nigeria,

- To ensure a rapid development of all parts of the country,

- To expand the local market,

- To reduce the fear of ethnic domination (it was obvious that overt and covert decisions of the colonial government especially between 1946 and 1966 negated these principles tragically),

- To apply diverse laws to suit diverse peoples, (in Nigeria this sometimes only helped to exacerbate not integrate the communities of Nigeria, the Indirect Rule, the exclusion of missionary schools from the North for long),

- The preservation of local independence or autonomy to every ethnic group (that was more injurious than catalytic for integration),

- To form a common and stronger government for the sovereignty of Nigeria (that stronger government has been unattained and unattainable), Access Library; 2016).

\section{Nigerian Federalism and its Jinx, the Factors of Strength as Factors of Weakness}

Many definitions of federalism prevail. Elazar, Blindenbach \& Watts define it as '.....a system of self-rule and shared rule' (1991; 5) define it as 'a multi-tiered government combining elements of shared rules and self-rule (2003; 9, Watts, 1996, p. 6). It is not an absolute hierarchy between different levels of government. The rights of each level in any federal system must be constitutionally guaranteed providing the autonomy of constituent governments in certain areas.

In some states, these rights 'are only on paper'. Many states are indeed 'highly centralized' in practice. There must be separation of powers supported by the creation of the legislative and the judiciary as viable course of government. No ideal form of federation, several variations exist, it is not an ideal system.

Nigeria is uniquely federal from the start, i.e. from colonialism. It has most times referred to itself as a federal public even whilst under the military's rampaging centralized structure. Several scholars argue about the virtues of federalism albeit controversially and dynamicly. Some ascribe to federalism 'economic efficiency' (Diamond; 1999; Weingost 1995); fosters democracy (Boix; 2003, Elazar; 1993); safeguards minority rights and creates equality (Lijphart; 1999), recognizes prevailing diversity (Harowitz; 1985 and 2003). Opponents fiercely disagree insisting that federalism might not enhance democracy (Castles; 1999, Filippon \& Shvetsova; 2011), it is usually short-lived in developing countries often adopted prior to disintegration (Manihool; 1984;521). It has been difficult to decipher the precise reasons why Britain resolved to prefer to introduce federalist governance into Nigeria. Some point to a 'divide and rule' strategy by Britain and add that post-independence African leaders spurned federalism preferring unitarist system but which also failed. With the cataclysmic graduation of unitary into military rule and the uniform failure of militarism, attention re-shifted to federalism as an option.

The basic feature of heterogeneity, the foundation for demands of concessional unity by component parts, works in both directions - as a catalyzing factor and as a destabilizing factor. It could be a product of the level of development of the specific country. The quest for an equitable share of limited resources usually produces frequently unhealthy and sordidly selfish struggle to seize advantage over co-competitors. This leads to the issue, 'does federalism enhance or resist development?' This has to be taken along with the over-arching ideology of democracy.

There are ingredients in federalism that appear compelling in democracy; consensus, bargaining, compromises, negotiations, peaceful conflict-resolution using legal and civil society mechanisms. These indices appear to be working efficaciously in some federal countries like the USA, Canada, Switzerland, Australia, New Zealand although there are palliatives and some brand or another of affirmative, redressive consultation mediums to tackle emerging and occasional social tensions. Summing up the growing emergence of federalism following the $2^{\text {nd }}$ World War, Elazar (1981:5; 1991:6;1993;194 concluded that 'the federalist revolution had been widely and successfully used' better than at any other previous time. Conversely, the ingredients of democracy are much wider and more diverse than those of federalism. Federalism seems to connote staticness even as volatile and unpredictable as its structures and component parts which are difficult to alter or to push away. Democracy on the other hand tends to yield complications that stare the citizenry and the rulers in the face on a continual and continuous basis. Nigeria conducted a massively contentious general election early in 2015, yet its fall-out, aftermaths and mop-ups have continued to spiral with intensity and ferocity virtually daily.

None of the substantive groups quarrels with the federalist structure of Nigeria although some extremists 
repudiate the entire concept of Nigeria; Boko Haram, MASSOB, Niger-Delta, the pro-Biafran movement.

When the jinx or doom factor is mentioned, it appears no more than pieces of speculation. The factor of underdevelopment appears as 'more pragmatic explanation for the sloggishness of democracy and the slow stabilization of federalism'. In any case developing countries are anxious to telescope the several centuries-old achievements of some developed countries into a few decades without the route of violent revolutions, which is often difficult to achieve.

\section{Any Alternative to Federalism?}

Nigeria was cobbled up from its original kingdoms, towns, empires, principalities, settlements that throve, up to 1884/85 when European powers under German Chancellor Bismarck presided over his convened Berlin Conference to discuss the division, distribution and allocation of the African continent. These countries including Lagos (colonized in 1861) had persisted on their own, although there was the umbrellic presence of the Oyo Empire, the Ibadan military presence, the Benin Empire, the Kanem-Borno Caliphates, and other potentates until the British intervention pre and post-1900. The fate of the ownership of Nigeria was sealed when in 1906, Lagos was conjoined to the Southern Provinces and conclusively in 1914 when Lord Frederick Lugard was anointed as Governor General of an amalgamated Nigeria. The decision by the British Government to merge the two protectorates into one country is evidentially for administrative and fiscal convenience. Although the heterogeneity of Nigeria was clear, even then the experiment needed a few decades to test its suitability. That appropriateness was questioned by Governor Bourdillon in 1939 when he proposed a federal structure for Nigeria because of its bigness and heterogeneity. This proposal was formalized by his successor Governor Richards who drafted and promulgated the 1946 Richards Constitution dividing Nigeria into three distinct Eastern, Western and Northern Regions of Nigeria.

Nigeria was a unique country in many respects, the colonial masters could have left as a big unitary administration as it was between 1900 and 1946, but the reality of the hugeness and complexity of the country could have led to the abandonment of the unitary option. KC Wheare insists that modern federations must have:

'A new military insecurity and of the consequent need for common defence, a desire to be independent of foreign powers, and a realization that only through union could independence be secured, a hope of economic advantage from union; some political association of the communities concerned prior to their federal union; either in a loose confederation, as with the American states and the Swiss cantons, or as parts of the same Empire, as with the Canadian and Australian colonies; geographical neighborhood; and a similarity of political institution', (KC Wheare p. 37)

Nigeria settled into federalism based on the 1954 Lyttleton Constitution, the Independence Constitution of 1960 and the Republican Constitution of 1963 only to run into a gale of torments and trauma of national derailment. The culmination of the fiasco that gripped the nation was the brutally bloody coup of Jan 15, 1966 and the even bloodier revenge coup of 29 Jul 1966. To many analysts, ethnicity and regionalism were the 'most important factors that wrecked the first republic (Ojo Emman O; 2014; A Critique of Some of the Available Sources on Nigerian History; International Journal of History \& Philosophical Research, 2(1), Mar 2014). Despite the grisly debacle of the nation, sanity was restored and the new Head of State Gen Yakubu Gowon repudiated dictatorship in his speech to the Ad Hoc Constitutional Conference in Lagos on Sep 12, 1966 by promising to:

'Discontinue the experience of pre-independence days, the incidents of May last in Northern Nigeria following the tendencies to extreme unification during the period after January 17 points to one and only one thing, that a country as big as Nigeria and comprising such diversity of tribes and cultures cannot be administered successfully under Unitarianism form of government unless such a government is to be enforced and maintained by some kind of dictatorship',46 (Elaigwu and Akindele; 1996 pg. 170). Expectations have largely remained a mirage on all fronts in the face of ineffectual and mundane panaceas.

As consequence, it is feasible to see federalism as a protagonist as well as nemesis within Nigeria's evolution. Given the discerned bigness of Nigeria's territorial spread along particularly with its heterogeneity, it would have been starkly difficult to continue to govern it unitarily as was done between 1900 and 1946 . The consequential effects of the international flow-out from the World War II, the multiple pressures from the colonies for independence and the United Nations and American pressure in support of liberty and freedom, higher education and greater democracy reinforced the craving for federalism-based independence in India, East Asia countries including Malaysia, Ceylon and others.

\section{Conclusion}

Federalism has bred multiple challenges, crises, dissentions. However, it has also provided opportunities for 
togetherness, for keeping Nigeria together amidst consecutive and concurrent twists and turns, trauma and hope. Selecting the fragility of Nigerian governance experience between 1900 and 1946 (during which there was only a nominal Nigerian country) and January to July 1966 (when the military tried to force a united Nigeria down the throats of Nigerians albeit abortively), it seems clear that federalism is the choice for Nigerian governance - as an entity. The stiff task is how to achieve a purification of the ideology of federalism to achieve substantive happiness for the greatest number, a task that seemed to have been unsuccessfully tackled by military and civilian elite over the pre and post-independence experience.

Nigerian federalism is always a topic and task carrying a worrisome quantum of controversy, apprehension and perturbation. Nonetheless, as Sam Momah concluded 'like the beetle, Nigeria will never die', no matter how vilified, bartered and pummeled.

'Nigeria has bright chances of becoming a regional, continental and ultimately a global powerhouse as long as there is a collective effort to deal with its major issues summarized as Poor Leadership, Corruption, Insecurity (and Terrorism), Poor Infrastructure, Bloated Bureaucracy, Federal Label by Unitary Content, Population Explosion, Very Low Productivity aggravated by Federal Character, Growing Religious Tension, Undiversified Economy and Unemployment Time-Bomb' under the canopy of Elaigwu J. I. and Akindele R.A; 1996, ibid, pg. 170 .

Federalism(Momah Sam; 2013; ibid, p. 244). A major task is to find ways to unite the country towards a genuine nation and departure from the current 'feeding-bottle federalism'. A frequently suggested panacea is to de-centralise the country by reversing the gross centralist decisions of military rule. Adescent is needed to return the country to at least some of the pre-1966 institutional liberties by reducing the current heavy-loaded items of the Exclusive List in the Nigerian Constitution, return to some regionalism of the 50s and 60s inside which ' .........there was hope, there was peace, there was progress in all major spheres of human endeavour. People travelled even at night because armed robbery was unheard of. At that time, the Minister of Lagos Affairs (Yar'Adua) was from the North. The Mayor of the Enugu was also from the North'..........the youths from various parts of the country converged in secondary schools and universities for education but more importantly in building the nation through the fusion of unity in diversity' (ibid, p. 238-9).

True federalism is hardly achievable in a country which inherited a lopsidedness, wobbled system and an ill-thought-out contrivance bequeathed to very brainy regional exemplary leaders who excelled regionally but failed woefully nationally. With its population and pedigree, Nigeria is largely a poor country "Nigeria even fares poorer than other developing countries like India and Brazil........the National Assembly passed a budget of about N475trillion (approximately \$30billiion) for 2012, but the Brazilian city of Sao Paulo made over N52billion in taxes as far back as 2005........over 100million people live on less than $\$ 1$ a day and majority of them are condemned to dynastic poverty" (Irikefe, ibid, p104). This crushing depiction is similar to Chinua Achebe's 1983 verdict:

"Nigeria is not a great country. It is one of the most disorderly nations of the world.........one of the most corrupt, insensitive, inefficient places under the sun, that give least value for money. It is dirty, callous, noisy, ostentatious, dishonest and vulgar. In short, it is one of the most unpleasant places on earth” (Achebe, p,11)

Just as in pre-independence, Nigeria does not move in one direction, it is a nation of nations. The centrifugal forces are huge and endemic, nonetheless, human beings must seek to progress, to advance, to improve from A to $\mathrm{B}$ to $\mathrm{H}$ to Z. Much bigger and equally heterogenous countries like India, China and Brazil, have achieved development reputation and economic distinction. The push factor has to be related to leadership and followership capacity and the resolve of the political elite to forge a forward movement by borrowing from relevant achievement models like Singapore, India, Brazil and Mal aysia. The absence of radically swift solutions to federalism-crises is a disability whilst the velocity of quick and potentially mistaken governance decisions in dictatorships lead to a continued validity and preference for federalism as against dictatorship or militarism even as circumstances compel society to live with, absorb and sanitize the concurrent dissonance of federalism to retain its protagonist status. The Nigerian citizenry is not happy waiting for development which is uncertain to come, development itself is a long-drawn-out process just like democracy. However it is likely that an improved federalism can assist to push the slow Nigerian movement faster and surer.

\section{References}

$\begin{array}{ccccc}\text { Access Library } & \text { (2016). Federalism in } \\ \text { http://accessportal.blogspot.comng/2009/07/federalism-in-nigeria.htm }\end{array}$

Achebe, C. (1982). The Trouble with Nigeria; Portsmouth, NH, Heinemann Educational. 
Adeolu, A. (2010). The Evolution of Politics via Excellence in Leadership; Ibadan University Press p.62,

Adeolu, A. (2010). The Evolution of Politics via Excellence in Leadership, Resource Control; Ibadan, University Press, p102.

Ajayi, O. (2012). Nigeria; Africa’s Failed Asset; Ibadan, Bookcraft, p 145,

Ajayi, O. (2015). Nigeria: Political Power Imbalance; Ibadan, Safari Books Ltd, p 145,

Akinjide (2000). Democracy and the Challenges of Succession in Nigeria. Retrieved from http://nigerdeltacongress.com/articles/democacy_and_the_challenges_of_htm

Akinjide, R. (2001). Democracy and the Challenges of Succession in Nigeria. Retrieved from http://nigeriadeltacongress_congress_com/articles/democray_and_the_challenges_of_htm

Ayoade, A., \& Ojo (2014). Nigeria Descent into Anarchy \& Collapse, Ibadan, John Archers Ltd).

Ayoade, J. A. A. (2010). Nigeria: Positive Pessimism and Negative Optimism. A Valedictory Lecture.

Ayoade, J. A. A., Akinsanya, A. A., \& Ojo, J. B. O. (2014). Nigeria; Anarchy and Collapse? Ibadan, John Archers Ltd p113.

Boix (2003). Modernisation and Democracy: Theories and Evidence Revisited, Retrieved from http://democracy.livingreviews.org

Elaigwu, J. I., \& Akindele, R. A. (1996). Foundations of Nigerian Federalism 1960 - 1995; Abuja, National Council on Intergovernmental Relations, p. 170.

Elaigwu, J. I., \& Akindele, R. A. (1996). Nigeria in the Global Market of Experiments in Federalism, Abuja, Nat Council on Intergov Relation.

Elazar, D. J. (1981). Exploring Federalism; Univ of Alabama Press.

Eneanya, N. A. (2014). Theory \& Practice of Public Administration; Ibadan University Printery, 552-564.

Fakanbi, K., \& Raji, O. (2013). The African Symposium; A Federation in Disarray: An Interrogation of National Integration and Security Challenges of Nigeria's Fourth Republic, 13(2).

Falola, T. (2016). Nigerian Political Modernity and Postcolonial Predicaments; Texas, Pan African University Press, 186-193.

First, R. (1970). Barrel of a Gun; London, the Penguin Press, p.54.

International Encyclopedia of the Social Sciences (1968). (Thomson Gale 2008) 'federation, Facts, information pictures. Retrieved from http:www.Encyclopaedia.com/topic/federalism.asp

Irikefe, P. O. (2013). Why Nigeria Is Not Working; The Predicament and the Promise; Ibadan, Kraft Books Ltd p.71,

Itse, S. (2013). Nigerian Constitution, Operation of Federalism and the South South Zone....A Keynote Address to the All-Nigeria Peoples Conference 2006 Grand Hayatt DFW, Dallas Texas, USA, 11 Nov 2013,

John, C. (2010). Nigeria: Dancing on the Brink; Ibadan, Bookcraft, p 8.

Karl, M. (2000). The House Has Fallen, London, Penguin Books, p xx 'Nigeria is not a developing nation, it is underdeveloping', ibid. p.xxi,

Lijphart (1999). Patterns of Democracy; New Haven; Yale University Press.

Meredith, M. (2005). The Fate of Africa; A History of the Continent Since Independence; New York, Public Affairs).

Meredith, M. (2005). The Fate of Africa; A History of the Continent Since Independence; New York, Public Affairs. p.75.

Nwabueze, B. O. (1983). Federalism in Nigeria under the Presidential Constitution, London; Sweet \& Maxwell, p.36.

O’Connell, J. (1967). The Inevitability of Instability; Journal of Modern African Studies, vol. A5/2, 181-191; Ugoh, S. C., \& Ukpere, W. I. (2012). The Ine vitability of Conflict; Policy of the Federal Character Principle \& Conflict Management in Nigerian Federalism. African Journal of Business Management, 6(23), 6771-6780.

Obiozor, A. G. (2015). Nigerian Politics, Leadership, and Nation Building. 
Odion, P. (2011). A Critical Assessment of Nigerian Federalism: Path to a True Federal System, Vanguard ng 30/11/2011.

Odion, P. (2011). A Critical Assessment of Nigerian Federalism: Path to a True Federal System, Vanguard ng $30 / 11 / 2011$.

Ojo, E. O. (2009). Federalism and the Search for National Integration in Nigeria; African Journal of Political Science \& International Relations, 3(9), 384-395.

Phillipson Report in Federalism in Africa; Problems and perspectives; 2016; Russian Academy of Sciences.

Sam, M. (2013). Nigeria Beyond Divorce, Amalgamation in Perspective; Ibadan, Safari Books Ltd.

Stanford Encyclopedia of Philosophy (2003). Federalism Reytrieved from http://plato.Stanford.edu/entries/federalism

Tepecikiioglu, E. E. (2012). The Promise of Federalism for Africa, Paper presented at $4^{\text {th }}$ ECPR Graduate Conference. Jacobs University, Breinen, 4(6), p8.

Title of Eghosa E Osaghae’s classic 2011; Crippled Giant; Nigeria Since Independence; Ibadan, John Archers Ltd.

Wheare, K. C. (1967). Federal Government; London, Oxford University Press, ibid, p 37.

\section{Copyrights}

Copyright for this article is retained by the author(s), with first publication rights granted to the journal.

This is an open-access article distributed under the terms and conditions of the Creative Commons Attribution license (http://creativecommons.org/licenses/by/4.0/). 